\title{
Genome size variation and evolution in North American cyprinid fishes
}

\author{
JR Gold*, CJ Ragland, LJ Schliesing \\ Department of Wildlife and Fisheries Sciences, Texas $A$ \& $M$ University, \\ College Station, TX 77843 , USA
}

(Received 4 January 1989; accepted 11 October 1989)

\begin{abstract}
Summary - Genome sizes (nuclear DNA contents) were documented spectrophotometrically for 29 species of North American cyprinid fishes. The data were then merged with comparable genome size data (published previously) from an additional 20 North American cyprinid species. The distributions of DNA values within populations of the 49 cyprinid species were essentially continuous and normal. The proportion of DNA which apparently is free to vary quantitatively within cyprinid populations appears to be between 4 and $5 \%$ of the genome. The distribution of DNA values among cyprinid species was more-or-less continuous, with considerable overlap among species with intermediate DNA values. Analysis of the average genome size difference (distance) between individuals drawn from successive levels of evolutionary divergence indicated that: (i) the majority of genome size divergence in North American cyprinids has occurred above the level of individuals within populations of species, and (ii) the degree of genome size divergence in the extremely speciose cyprinid genus Notropis is greater than that between species in other, less speciose cyprinid genera. The hypothesis that genome size change might be concentrated in speciation episodes was tested by comparing the means and variances of genome size difference (distance) between species in the cyprinid genus Notropis (a species-rich phylad) and the centrarchid (sunfish) genus Lepomis (a species-poor phylad). The ratios of mean distances and variances in the Notropis versus Lepomis comparisons were greater than unity, suggesting that changes in genome size in cyprinids may be correlated with speciation episodes. Whether or not genome size change in cyprinids occurs at speciation sensu strictu is problematic. The data suggest that separate facets or levels of the cyprinid genome may follow independent evolutionary paths.
\end{abstract}

genome size (DNA content) / cyprinid fish / natural selection / speciation

Résumé - Variation et évolution de la taille du génome chez les cyprinidés d'Amérique du Nord - La taille du génome (estimée par la quantité d'ADN nucléaire) de 29 espèces Nord-Américaines de cyprinidés a été mesurée par spectrophométrie; les résultats ont ensuite été jumelés à des données comparables publiées antérieurement, obtenues sur 20 autres espèces de cyprinidés de la même aire géographique, et les analyses ont été conduites sur l'ensemble de ces données. Au sein des populations, la quantité d'ADN nucléaire suit une distribution continue et normale, et varie dans une proportion qui représente $4 \grave{a}$ $5 \%$ du génome. Etudiée sur l'ensemble des espèces, la quantité d'ADN nucléaire présente une distribution quasiment continue, avec des chevauchements considérables entre espèces.

* Correspondence and reprints 
L'analyse de la variation observée parmi des individus tirés dans des niveaux taxonomiques variés indique que:

- la variation est essentiellement due aux variations entre espèces et non aux variations entre individus d'une même espèces, et que,

- la variation entre espèces est plus étendue dans le genre Notropis que dans d'autre genres moins diversifiés. L'hypothèse selon laquelle les modifications de taille génomique seraient concentrées à l'occasion d'épisodes de spécification a été testée en, comparant, dans 2 groupes différant par leur degré de différentiation, les moyennes et les variances des écarts constatés entre les différentes espèces au sein de chaque groupe: le genre Notropis (cyprinidés), phylum riche en espèces, et le genre Lepomis (centrarchidés, poissons-lunes), phylum pauvre en espèces. Les rapports des moyennes et des variances de Notropis comparées à Lepomis sont tous 2 supérieurs à l'unité, ce qui suggère une corrélation entre les variations de taille génomique et les épisodes de spéciation chez les cyprinidés; la relation exacte entre de tels changements et la spéciation sensu stricto demande cependant à être précisée. Les résultats suggèrent enfin que les processus évolutifs sont susceptibles de différer en fonction des facettes envisagées du génome des cyprinidés.

taille du génome (quantité d'ADN) / cyprinidés / sélection naturelle / spéciation

\section{INTRODUCTION}

It has been known for several years that sizeable differences in genome size or DNA content often occur, even between closely related species (Mirsky and Ris, 1951; Bachmann et al, 1972; Sparrow et al, 1972. Kauffman (1971) initially hypothesized that the extensive genome size variation was related directly to organismal and/or genetic complexity. It is now clear, however, that no significant correlations exist between genome size and organismal (or genetic) complexity or phylogenetic advancement (Cavalier-Smith, 1985a; Price, 1988a). This has been termed the Cvalue paradox and represents a general biological problem among eukaryotes which to date remains unresolved (Price, 1988a,b,c).

Efforts towards explaining or understanding the $\mathrm{C}$-value paradox have been focused primarily on the search for significant correlations between genome size and a variety of biological, biophysical or genetic parameters. What has emerged from these studies are several hypotheses which relate genome size in an inverse way to rates of organismal growth, metabolism or differentiation, and which invoke selection as the primary force responsible for the observed variation in genome size (Bennett, 1971, 1972; Cavalier-Smith, 1978, 1980, 1985a, b; Szarski, 1983; Sessions and Larson, 1987; Price 1988a).

These hypotheses are confounded for several reasons. First, much of the data which document relationships between genome size and cell cycle patterns or certain life history parameters are from unicellular eukaryotes (eg, Cavalier-Smith, 1980; Shuter et al, 1983). The problem lies in the extrapolation to multicellular eukaryotes where it is often difficult to obtain direct, unbiased or standardized estimates of organismal growth and/or developmental rates. A second reason is that most, if not all, of the evidence is correlative and does not necessarily demonstrate cause and effect. A third reason is that nearly all of the genome size data are from distinct species or higher level taxa. Studies of genome size variation at lower hierarchical levels are few, and differences in genome size within species generally have been regarded as insignificant or unimportant (Bennett and Smith, 1976). Several recent studies, however, have shown that intraspecific variation in 
genome size may be substantial, and in some cases approximate the average genome size differences observed between species (Price et al, 1981, 1986; Sherwood and Patton, 1982; Gold and Price, 1985; Gold and Amemiya, 1987; Johnson et al, 1987; Ragland and Gold, 1989). A final reason is that little attention has been paid to the mechanisms by which DNA might be gained or lost from a genome. The observations that species within cohesive groupings ( $e g$, genera) often differ substantially in genome size and that interspecies genome sizes are frequently discontinuously distributed have led to the suggestion that genome size evolution may occur in a "quantized" fashion; ie, by a succession of large-scale changes (Narayan, 1982; Cavalier-Smith, 1985b). Subsumed within this problem is the question of whether genome size changes might be occurring disproportionally during speciation episodes. Several authors (Hinegardner, 1976; Morescalchi, 1977; Cavalier-Smith, 1978) have suggested that genome size change might be associated with speciation, although a direct correlation between genome size change and speciation has not been tested critically.

In the following, data on intra- and interspecific genome size variation among 49 species of North American cyprinid fishes are presented. The genome size data from 29 of the species are given for the first time. The subjects of primary interest in the paper are: (i) the pattern and magnitude of genome size variation within populations and among species, and (ii) the question of whether genome size changes are concentrated in speciation episodes.

\section{MATERIAL AND METHODS}

The collection localities of samples representing the 29 North American cyprinid species, whose genome sizes are reported here, are given in the Appendix, Table AI. All fish were collected by seine from natural populations. Fish sampled from Texas (TX) and Louisiana (LA) were returned live to our laboratory in College Station for processing; fish sampled from Oklahoma (OK) and Alabama (AL) were processed in facilities at the Oklahoma University Biological Station on Lake Texoma and at Samford University in Birmingham, AL, respectively. Except for Notropis lepidus, the samples of each species comprised 5 individuals taken from the same locality. The $N$. lepidus sample comprised 10 individuals from the same locality. Collection localities for the 20 other North American cyprinid species included in the data analyses in this paper, may be found in Gold and Amemiya (1987). In that study, the samples of each species comprised 10 individuals taken from the same locality.

Genome sizes were measured via scanning microdensitometry of Feulgen-stained erythrocyte nuclei using chicken blood as an internal control. The latter was obtained from a highly inbred, pathogen-free strain available from the Texas A \& M College of Veterinary Medicine. Full details of slide preparation, staining and microdensitometry may be found in Gold and Price (1985) and Gold and Amemiya (1987). Fifteen erythrocyte nuclei were measured from each of 2 slides per fish (=30 nuclei/individual) and standardized as a percent of the mean absorbancy of 10 chicken erythrocyte nuclei on the same slide. Standardized absorbancy values of fish nuclei were coded (for convenience) by multiplying the percent chicken standard (for each fish nucleus) by 20 . Statistical analyses of the data were carried out using either SAS (1982) or our own programs on the Texas A \& M mainframe computer. 
Means, standard errors and ranges for the 29 species were taken from the distribution of DNA values of individuals within each species. Distribution normality indices $\left(g_{1}\right.$ and $\left.g_{2}\right)$ were taken from the distribution of measurements (nuclei) within each species. Descriptive statistics of genome size variation within and among the 20 cyprinid species not reported here may be found in Gold and Amemiya (1987). The methodologies used to determine genome sizes of individuals in all 49 species were identical. The current classification of the 49 species is shown in the Appendix, Table AII. Note that 31 of the 49 species are from the extremely speciose genus Notropis which includes over 125 species (Lee et al, 1980).

\section{RESULTS}

Descriptive statistics (means \pm standard errors, ranges and the $g_{1}$ and $g_{2}$ indices of distribution normality) for the 29 species are given in Table I. Genome sizes ranged from $2.06 \mathrm{pg}$ of DNA in Notropis callistius to $3.26 \mathrm{pg}$ of DNA in Phenacobius catostomus, a difference of approximately $58 \%$. The ranges of genome sizes within each of the 29 species varied in percent from 1.15 in Notropis bellus to 8.74 in Dionda episcopa, and averaged 4.11. Five of the 29 sampling distributions of measurements (nuclei) within each species were significantly non-normal. Of the 5,3 were significantly platykurtic or flat, and 2 were significantly skewed towards higher DNA values.

\section{Patterns and magnitude of genome size variation within populations of species}

The coded absorbancy data from the 49 cyprinid species examined to date were organized into a number of different sampling distributions and each was tested for distribution normality using the $g_{1}$ and $g_{2}$ indices. The distributions tested included: (i) all measurements (nuclei) within each population (species) or sample (49 sampling distributions; $N=300$ for populations where 10 individuals were examined and $N=150$ for populations where 5 individuals were sampled); and (ii) a rankit distribution (Sokal and Rohlf, 1969) reflecting the distribution of DNA values of individuals within populations summed over all 49 populations. The latter was generated following eqn[1] in Gold and Amemiya (1987) in order to remove scaling effects due to individuals being drawn from different species. The results of the distribution normality tests are summarized in Table II. The majority of the distributions of measurements (nuclei) within populations were normal, although the incidence of non-normal distributions was higher than expected by chance at $\alpha=0.05$. The rankit distribution reflecting the distribution of DNA values of individuals within populations was significantly platykurtic, although the deviation appears slight (Fig 1).

Separate single classification analyses of variance (ANOVA) were used to test for significant heterogeneity of DNA values of individuals within each of the 49 populations (species) using the distribution of measurements (nuclei) of that species. All F-tests were significant at $\alpha=0.05$. A synopsis of the results of Duncan's multiple range test on each population is shown in Table III. The results demonstrate that significant differences in genome size occur among individuals 
Table I. Descriptive statistics of genome size variation among 29 species of North American Cyprinidae. Means and ranges are from the distributions of DNA values of individuals where $N=5$ for each taxon except Notropis lepidus, where $N=10$. Distribution normality statistics are from the distributions of measurements (nuclei) where $N=150$ for each taxon except Notropis lepidus, where $N=300 .{ }^{*}$ Significant at $\alpha=0.05$. Positive $g_{1}$ values indicate skewness towards higher values; negative $g_{2}$ values indicate platykurtosis.

\begin{tabular}{|c|c|c|c|c|}
\hline \multirow[b]{2}{*}{ Taxon } & \multicolumn{2}{|c|}{$2 C D N A$ content $(p g)$} & \multicolumn{2}{|c|}{$\begin{array}{c}\text { Distribution } \\
\text { normality } \\
\text { statistics }\end{array}$} \\
\hline & Mean $\pm s e$ & Range (\%) & $\begin{array}{c}\text { Skewness } \\
\quad\left(g_{1}\right)\end{array}$ & $\begin{array}{c}\text { Kurtosis } \\
\left(g_{2}\right)\end{array}$ \\
\hline \multicolumn{5}{|l|}{ Genus Notropis } \\
\hline $\begin{array}{l}N \text { amabilis } \\
N \text { ardens } \\
N \text { atherinoides } \\
N \text { atrocaudalis } \\
N \text { baileyi } \\
N \text { bellus }\end{array}$ & $\begin{array}{l}2.46 \pm 0.03 \\
2.49 \pm 0.03 \\
2.37 \pm 0.01 \\
2.90 \pm 0.02 \\
2.79 \pm 0.02 \\
2.61 \pm 0.01\end{array}$ & $\begin{array}{l}2.38-2.54(6.72) \\
2.39-2.55(6.69) \\
2.33-2.38(2.15) \\
2.84-2.95(3.87 \\
2.72-2.85(4.78) \\
2.60-2.63(1.15)\end{array}$ & $\begin{array}{r}0.328 \\
0.051 \\
0.053 \\
-0.011 \\
0.157 \\
-0.009\end{array}$ & $\begin{array}{l}-0.174 \\
-0.099 \\
-0.650 \\
-0.502 \\
-0.390 \\
-0.296\end{array}$ \\
\hline$N$ braytoni & $2.55 \pm 0.01$ & $2.50-2.58(3.20)$ & 0.064 & $-0.820^{*}$ \\
\hline$N$ callistius & $2.06 \pm 0.01$ & $2.01-2.10(4.48)$ & -0.132 & -0.243 \\
\hline$N$ camurus & $2.39 \pm 0.03$ & $2.29-2.48(8.30)$ & -0.053 & -0.669 \\
\hline$N$ chrosomus & $2.47 \pm 0.01$ & $2.45-2.50(2.04)$ & 0.047 & -0.321 \\
\hline$N$ emiliae & $2.08 \pm 0.01$ & $2.05-2.13(3.90)$ & -0.216 & -0.300 \\
\hline$N$ lepidus & $2.53 \pm 0.01$ & $2.47-2.57(4.05)$ & 0.042 & 0.106 \\
\hline$N$ oxyrhynchus & $2.08 \pm 0.02$ & $2.03-2.11(3.94)$ & -0.314 & -0.049 \\
\hline$N$ potteri & $2.35 \pm 0.03$ & $2.27-2.42(6.61)$ & -0.373 & -0.298 \\
\hline$N$ proserpinus & $2.89 \pm 0.02$ & $2.85-2.94(3.16)$ & -0.255 & -0.204 \\
\hline$N$ stilbius & $2.54 \pm 0.01$ & $2.51-2.59(3.19)$ & 0.200 & -0.224 \\
\hline$N$ texanus & $2.74 \pm 0.02$ & $2.69-2.80(4.09)$ & 0.230 & -0.622 \\
\hline$N$ trichroistius & $2.28 \pm 0.01$ & $2.24-2.31(3.12)$ & $0.456^{*}$ & 0.392 \\
\hline$N$ volucellus & $2.51 \pm 0.01$ & $2.47-2.54(2.83)$ & 0.330 & 0.349 \\
\hline \multicolumn{5}{|l|}{ Other genera } \\
\hline $\begin{array}{l}\text { Dionda episcopa } \\
\text { Ericymba buccata }\end{array}$ & $\begin{array}{l}2.13 \pm 0.03 \\
2.25 \pm 0.02\end{array}$ & $\begin{array}{l}2.06-2.24(8.74) \\
2.19-2.32(5.94)\end{array}$ & $\begin{aligned} & 0.508^{*} \\
- & 0.257\end{aligned}$ & $\begin{array}{l}-0.382 \\
-0.614\end{array}$ \\
\hline Hemitremia flammea & $2.37 \pm 0.02$ & $2.33-2.41(3.43)$ & 0.109 & $-0.902^{*}$ \\
\hline Hybognathus placitus & $2.81 \pm 0.02$ & $2.74-2.86(4.38)$ & 0.006 & -0.637 \\
\hline Hybopsis aestivalis & $2.49 \pm 0.01$ & $2.45-2.52(2.86)$ & 0.233 & -0.192 \\
\hline Nocomis asper & $2.50 \pm 0.01$ & $2.48-2.54(2.42)$ & 0.233 & $-0.945^{*}$ \\
\hline $\begin{array}{l}\text { Nocomis leptocephalus } \\
\text { Phenacobius catostomus }\end{array}$ & $2.49 \pm 0.01$ & $2.48-2.51(1.21)$ & 0.227 & -0.436 \\
\hline $\begin{array}{l}\text { Phenacobius catostomus } \\
\text { Phenacobius mirabilis }\end{array}$ & $3.26 \pm 0.02$ & $3.21-3.35(4.36)$ & 0.128 & -0.464 \\
\hline $\begin{array}{l}\text { Phenacobius mirabilis } \\
\text { Rhinichthys atratulus }\end{array}$ & $3.24 \pm 0.02$ & $3.18-3.31(4.09)$ & 0.149 & -0.154 \\
\hline Rhinichthys atratulus & $2.58 \pm 0.02$ & $2.52-2.61(3.57)$ & -0.270 & -0.010 \\
\hline
\end{tabular}

within cyprinid populations and that, on average, approximately half of the individuals from any given population differ in DNA content. 
Table II. Summary of genome size variation within populations of 49 species of North American Cyprinidae. ${ }^{a} \mathrm{PK}=$ platykurtic; $\mathrm{SR}=$ skewed towards higher values; $\mathrm{SL}=$ skewed towards lower values; all deviations from normality were significant at $\alpha=0.05$;

b Rankit distribution of DNA values of individuals ( $c f$ text);

c From Duncan's multiple range tests ( $c f$ text).

\begin{tabular}{lc} 
No. populations surveyed & 49 \\
Measurements (nuclei) & $37 \mathrm{Normal}^{\mathrm{a}}$ \\
within populations & $6 \mathrm{PK}^{\mathrm{a}}$ \\
& $4 \mathrm{SR}$ \\
& $1 \mathrm{SL}$ \\
& $1 \mathrm{PK}, \mathrm{SR}$ \\
Individuals within populations $^{\mathrm{b}}$ & $\mathrm{PK}$ \\
$\begin{array}{l}\text { Av No. significantly different } \\
\text { groups within populations }\end{array}$ & $4.48(N=10 ; 21$ populations) \\
$\begin{array}{l}\text { Av maximum genome size } \\
\text { variation within populations }\end{array}$ & $2.79(N=5 ; 28$ populations) \\
\hline
\end{tabular}

The magnitude of genome size variation within cyprinid populations was estimated as the average of the percent maximum variation between individuals within populations. These values ranged from $1.15 \%$ in Notropis bellus (Table I) to $13.49 \%$ in Notemigonus crysoleucus (Table 3 in Gold and Amemiya, 1987), and averaged $4.86 \pm 0.31 \%$ (Table II). Assuming an average North American cyprinid genome size of $2.47 \mathrm{pg}$ of DNA, this represents approximately $0.12 \mathrm{pg}$ or about $1.1 \times 10^{8}$ base pairs of DNA.

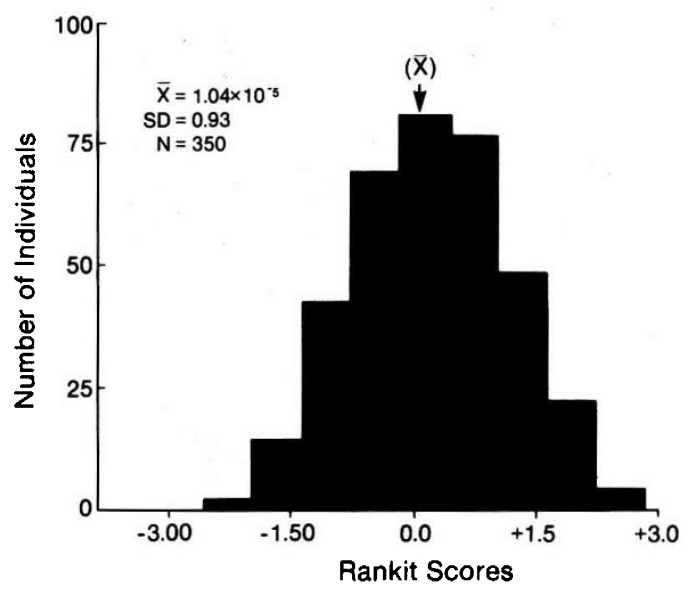

Fig 1. Frequency distribution of rankit scores ( $c f$ text) reflecting the distribution of individuals within populations. 


\section{Patterns and magnitude of genome size variation among species}

A plot of the distribution of DNA values of individuals examined from all 49 species is shown in Fig 2. With the exception of the 2 species of Phenacobius (cf Table I), the interspecies distribution of genome sizes appears continuous and overlapping. Single classification ANOVA was used to test for significant heterogeneity in genome size variation among species using this sampling distribution. Significant heterogeneity of mean DNA values at $\alpha=0.05$ was found and the results of a Duncan's multiple range test are shown in Table III. Again, with exception of the 2 species of Phenacobius, interspecies genome sizes appear more-or-less continuously distributed with considerable overlap among species with intermediate DNA values.

Table III. Results* of Duncan's multiple range test on the distribution of DNA values of individuals.

$\bar{X}$ : mean DNA value $(\mathrm{pg}) .{ }^{*}$ Mean DNA values of species with the same letter (Duncan's test grouping) are not significantly different at $\alpha=0.05$.

\begin{tabular}{llll}
\hline Species & $\bar{X}(\mathrm{pg})$ & Species & $\bar{X}(\mathrm{pg})$ \\
\hline Phenacobius catostomus & $3.26^{a}$ & Notropis amabilis & $2.46^{j, k}$ \\
Phenacobius mirabilis & $3.24^{a}$ & Notropis venustus & $2.42^{k, l}$ \\
Notropis atrocaudalis & $2.90^{b}$ & Notropis camurus & $2.39^{l, m}$ \\
Notropis proserpinus & $2.89^{b}$ & Notropis nubilus & $2.38^{l, m}$ \\
Hybognathus placitus & $2.81^{c}$ & Notropis rubellus & $2.38^{l, m}$ \\
Notropis baileyi & $2.79^{c}$ & Notropis lutrensis & $2.37^{l, m}$ \\
Notropis texanus & $2.74^{d}$ & Hemitremia flammea & $2.37^{l, m}$ \\
Notropis shumardi & $2.72^{d}$ & Notropis atherinoides & $2.37^{l, m}$ \\
Notropis umbratilis & $2.65^{e}$ & Notropis potteri & $2.35^{m, n}$ \\
Phoxinus erythrogaster & $2.63^{e, f}$ & Notropis girardi & $2.34^{m, n}$ \\
Notropis bellus & $2.61^{e, f}$ & Notropis chrysocephalus & $2.30^{n, o}$ \\
Rhinichthys atratulus & $2.58^{f, g}$ & Campostoma anomalum & $2.29^{o, p}$ \\
Notropis braytoni & $2.55^{g, h}$ & Notropis trichroistius & $2.28^{o, p}$ \\
Notropis stilbius & $2.54^{g, h}$ & Notemigonus crysoleucas & $2.28^{o, p}$ \\
Notropis lepidus & $2.53^{g, h, i}$ & Campostoma oligolepis & $2.26^{o, p, q}$ \\
Notropis stramineus & $2.51^{h, i, j}$ & Ericymba buccata & $2.25^{o, p, q, r}$ \\
Notropis volucellus & $2.51^{h, i, j}$ & Pimephales notatus & $2.24^{p, q, r}$ \\
Semotilus atromaculatus & $2.50^{h, i, j}$ & Pimephales promelas & $2.22^{q, r, s}$ \\
Nocomis asper & $2.50^{h, i, j}$ & Pimephales vigilax & $2.21^{r, s}$ \\
Notropis whipplei & $2.50^{h, i, j}$ & Notropis boops & $2.19^{s}$ \\
Hybopsis aestivalis & $2.49^{h, i, j}$ & Dionda episcopa & $2.13^{t}$ \\
Nocomis leptocephalus & $2.49^{h, i, j}$ & Notropis oxyrhynchus & $2.08^{u}$ \\
Notropis ardens & $2.49^{h, i, j}$ & Notropis emiliae & $2.08^{u}$ \\
Notropis pilsbryi & $2.48^{i, j}$ & Notropis callistius & $2.06^{u}$ \\
Notropis chrosomus & $2.47^{i, j}$ & & \\
\hline & & & \\
\hline
\end{tabular}




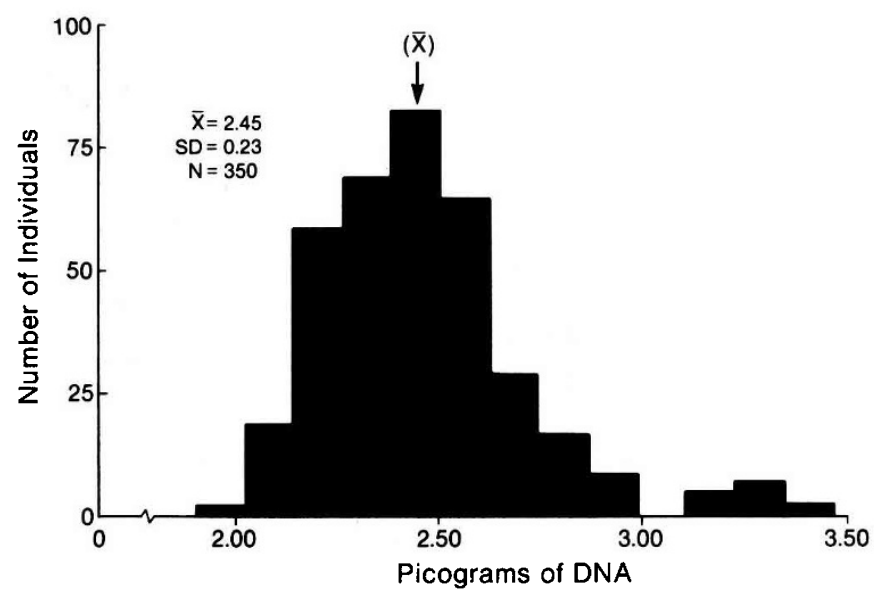

Fig 2. Frequency distribution of DNA values of individuals over all 49 cyprinid species. Individuals with genome sizes greater than $3.00 \mathrm{pg}$ of DNA are from the genus Phenacobius.

Two approaches were used to examine the magnitude of genome size variation among the 49 species. The first was to carry out a nested analysis of variance (Table IV) which revealed that, although significant heterogeneity in genome size existed at each experimental level from between slides within individuals to among species, the majority $(>88 \%)$ of the variation occurs among species. The second approach was to estimate the magnitude of genome size differences at ascending taxonomic levels. This was accomplished using eqns [2] and [3] of Gold and Amemiya (1987). Briefly, eqn[2] generates a genome size difference or distance $\left(\mathrm{GSD}_{\min }\right)$ value between 2 species or taxa which represents the average of all pairwise differences in genome size between all individuals sampled from each taxon or species ( $e g$, with $N=10$ individuals for each of 2 species, there are 100 possible comparisons). The $48 \times 49 \mathrm{GSD}_{\min }$ distance matrix (which includes $1176 \mathrm{GSD}_{\min }$ values) generated from these calculations is not shown but may be obtained, from the first author. Equation [3] generates a $\mathrm{GSD}_{\min }$ value which represents the average of all possible pairwise comparisons between all individuals of any one population of a species (eg, for $N=10$ individuals, there are 45 possible comparisons). The $\mathrm{GSD}_{\min }$ values for all 49 populations (species) were then averaged to obtain an estimate of the average genome size difference or distance between individuals within populations of species. It should be noted that both $\mathrm{GSD}_{\min }$ values are minimum linear distance metrics which underestimate the true distance if reversed or reticulated patterns of change occur (Sneath and Sokal, 1973).

The average genome size difference (distance) between individuals drawn from successive levels of evolutionary divergence are shown in Table V. Estimates of average genome size distances between species in subgenera of Notropis and between species in Notropis and in other genera were obtained from subsets of $\mathrm{GSD}_{\min }$ values extracted from the $48 \times 49 \mathrm{GSD}_{\min }$ distance matrix. The average genome size distance between species in subgenera of Notropis, for example, involved first 
Table IV. Nested analysis of variance. ${ }^{*}$ Significant at $\alpha=0.05$.

\begin{tabular}{lrrcrr}
\hline $\begin{array}{l}\text { Variance } \\
\text { source }\end{array}$ & \multicolumn{1}{c}{$D$} & \multicolumn{1}{c}{ MS } & \multicolumn{1}{c}{$\begin{array}{c}\text { Variance } \\
\text { component }\end{array}$} & $\%$ \\
\hline Total & 10499 & 3.86 & - & 3.94 & 100.00 \\
Species & 48 & 748.34 & $208.84^{*}$ & 3.48 & 88.46 \\
Individuals & 301 & 3.58 & $1.90^{*}$ & 0.07 & 1.44 \\
Slides & 350 & 1.88 & $6.43^{*}$ & 0.11 & 2.68 \\
Error & 9800 & 0.29 & - & 0.29 & 7.41 \\
\hline
\end{tabular}

computing the average genome size distance value for each subgenus based on all pairwise comparisons between species in that subgenus, and then averaging these values over all subgenera. The same method was used to estimate the average genome size distance between species in genera other than Notropis. The estimate for species in Notropis is simply the average of all pairwise comparisons among 29 of the 31 nominal Notropis species examined. Both $N$ atrocaudalis and $N$ stramineus were not included in the latter estimate since the phylogenetic affinities of these 2 species may lie outside of Notropis (Mayden, 1989). For similar reasons, $N$ rubellus and $N$ baileyi were not included in the genome size distance estimate for the Notropis subgenus Hydrophlox (Mayden and Matson, 1988). The genus Pimephales was included in the genome size distance estimate for species within the genus Notropis since Pimephales is now believed to be closely related phylogenetically to certain lineages within Notropis (Cavender and Coburn, 1986). The estimate for species in the family is the average of all pairwise comparisons among all 49 species examined.

As shown in Table $\mathrm{V}$, individuals drawn at random from a population of the same cyprinid species will differ, on average, by 0.388 genome size distance units (approximately $0.048 \mathrm{pg}$ of DNA); whereas, any 2 individuals drawn at random from 2 different North American cyprinid species will differ, on average, by 2.322 genome size distance units (approximately $0.290 \mathrm{pg}$ of DNA). This represents a 6 -fold difference and strongly suggests that the majority of genome size divergence in North American cyprinids has occurred above the level of individuals within populations of species. Particularly noteworthy are the observations that (i) the degree of genome size divergence between species in the genus Notropis is approximately 5 times that between species in other cyprinid genera, and (ii) much of the divergence in Notropis has apparently occurred at the subgeneric rather than generic level. The most actively evolving Notropis subgenera in terms of genome size appears to be Cyprinella and Notropis, where the average genome size distance between species was estimated as 2.152 and 2.340 units, respectively. Since these are the 2 largest Notropis subgenera in terms of number of species, and since Notropis itself contains considerably more species than Campostoma, Nocomis or Phenacobius, the tentative implication of these data is that there may be a positive relationship between the number of species within a group or subgroup and divergence in genome size. 
Table V. Average genome size difference (distance) between individuals from successive levels of evolutionary divergence. ${ }^{\text {a }}$ In coded DNA values. Picograms are estimated by dividing coded values by $8 ;{ }^{b}$ Average of mean genome size distances between species in 6 subgenera of Notropis ( $c f$ Appendix, Table AII); ${ }^{\mathrm{c}}$ Average of mean genome size distances between species in Campostoma, Nocomis and Phenacobius.

\begin{tabular}{llc}
\hline \multicolumn{1}{c}{ Level } & $\begin{array}{c}\text { Mean genome size } \\
\text { difference } \pm \text { se }\end{array}$ & $\begin{array}{c}\text { No of pairwise } \\
\text { comparisons }\end{array}$ \\
\hline $\begin{array}{l}\text { Individuals within } \\
\text { populations of species }\end{array}$ & $0.388 \pm 0.022$ & 1225 \\
$\begin{array}{l}\text { Species in subgenera } \\
\text { (of Notropis) }\end{array}$ & $1.327 \pm 0.316^{\mathrm{b}}$ & 44 \\
$\begin{array}{l}\text { Species in genera: } \\
\text { Notropis } \\
\text { other genera }\end{array}$ & $1.899 \pm 0.059$ & 496 \\
Species in family & $0.378 \pm 0.108^{\mathrm{c}}$ & 3 \\
\hline
\end{tabular}

\section{Genome size change and speciation}

The findings that the majority of genome size variation in North American cyprinids appears to occur at the species level or above, and that a relationship may exist between the number of species within cyprinid groups or subgroups and divergence in genome size, suggest that genome size changes in cyprinids may be concentrated in speciation episodes. Avise and Ayala $(1975,1976)$ and Avise (1978) developed models which contrast expected means and variances of genetic differences or distances among extant members of rapidly versus slowly speciating lineages or phylads, and which may be used to assess whether genetic differentiation is correlated with speciation. Briefly, if genetic differentiation is essentially a function of time (gradual evolution), the ratio of mean genetic distances between species-rich versus species-poor phylads should be approximately 1 , and the ratio of variances should be less than 1. Alternatively, if genetic differentiation is proportional to the number of speciation episodes (punctuated evolution), the ratio of distances should be greater than 1 , and the ratio of variances should be much greater than 1. There are several assumptions inherent in using the models, the most important of which is that the species-rich and species-poor lineages under comparison be of approximately equal evolutionary age (Avise and Ayala, 1975; Avise, 1978).

In Table VI, the mean $(\bar{d})$ and variance $\left(s^{2}\right)$ of average genome size differences (distances) among 32 Notropis species (including the 3 species of Pimephales) are compared with comparable values from 8 species of the centrarchid (sunfish) genus Lepomis. The distance and variance values were generated as before (ie, extracted from the $48 \times 49 \mathrm{GSD}_{\min }$ cyprinid data matrix, and from a similar Lepomis data matrix described in Ragland and Gold, 1989). For reasons noted previously, the 3 species of Pimephales were included into the estimates for Notropis, whereas 
$N$ atrocaudalis and $N$ stramineus were not. For similar reasons (GV Lauder, personal communication), Lepomis gulosus was not included in the calculations of $\bar{d}$ and $s^{2}$ values for the genus Lepomis. As shown in Table VI, the ratio of mean distances is greater than 1, and the ratio of variances is very much greater than 1 . According to the models, these results indicate that changes in genome size in cyprinids are correlated with speciation episodes. In Table VII, observed ratios of mean distances and variances for the comparison Notropis versus Lepomis and data from protein electrophoresis and morphological measurements are compared to those based on genome size. Taken at face value, the observed ratios suggest that differentiation in structural genes and morphology occurs primarily as a function of elapsed time.

Table VI. Comparisons of means $(\bar{d})$ and variances $\left(s^{2}\right)$ of average genome size difference (distance) between species-rich Notropis and species-poor Lepomis.

\begin{tabular}{lccccc}
\hline Test group & $\bar{d}$ & $\bar{d}_{r} / \bar{d}_{p}$ & $s^{2}$ & $s_{r}^{2} / s_{p}^{2}$ & No of species \\
\hline $\begin{array}{l}\text { Notropis } \\
\text { (species-rich) }\end{array}$ & 1.899 & & 1.752 & & 32 \\
$\begin{array}{l}\text { Lepomis } \\
\text { (species-poor) }\end{array}$ & 1.008 & 1.883 & & 7.121 & \\
\hline
\end{tabular}

Table VII. Mean distance and variance comparisons between Notropis (species-rich) and Lepomis (species-poor) at different levels of genome organization. ${ }^{a}$ Based on allele frequency differences at 11-24 genetic loci among 47 species of Notropis and 10 species of Lepomis (Avise, 1977); ${ }^{\mathrm{b}}$ Based on differences at 50 morphological characters among 37 species of Notropis and 11 species of Lepomis (Douglas and Avise, 1982); ${ }^{\mathrm{c}}$ This paper.

\begin{tabular}{lcc}
\hline & \multicolumn{2}{c}{ Notropis vs Lepomis } \\
\cline { 2 - 3 } Genome level & $\bar{d}_{r} / \bar{d}_{p}$ & $s_{r}^{2} / s_{p}^{2}$ \\
\hline Structural genes $^{\mathrm{a}}$ & 0.99 & 1.62 \\
External morphology $^{\mathrm{b}}$ & $0.87-1.04$ & - \\
Genome size $^{\mathrm{c}}$ & 1.88 & 7.12 \\
\hline
\end{tabular}

\section{DISCUSSION}

The normality (or near normality) of genome size distributions within populations of cyprinids strongly suggests that DNA quantity changes at this level are small, involve both gains and losses of DNA, and are cumulative and independent in effect. This hypothesis is based on the assumption that the variation follows the premises of the normal probability density function (Sokal and Rohlf, 1969). An 
identical pattern of variation also occurs among populations of 9 species of the North American centrarchid genus Lepomis (Ragland and Gold, 1989). Of importance is that no instance of a quantum or "quantized" (Cavalier-Smith, 1985b) difference in genome size among individuals has been found in the nearly 60 populations of cyprinids or centrarchids thus far studied. Comparable data from other organisms on genome size variation among several individuals within populations are few, and are limited primarily to the extensive researches by Price and colleagues on the plant Microseris douglasii (Price et al, 1981, 1986). In $M$ douglasii, genome size variation is also continuous with no evident, large-scale differences in genome size occurring among individuals within populations.

There was an apparent tendency towards platykurtosis in a few of the cyprinid populations genome size distributions, including the rankit distribution, which reflects the normalized variation of DNA values of individuals. Most of the deviations from normality, however, were slight and, in the case of the rankit values, the distribution only became platykurtic upon the addition of the 28 populations (species) reported in this paper, where sample sizes were restricted to only 5 individuals per population. This suggests that the observed platykurtosis may be a function of non-random sampling since typically most individuals were collected in only 1 or 2 seine-hauls and could represent close relatives ( $e g$, full-sibs) rather than individuals drawn at random from population.

The proportion of DNA, which apparently is free to vary quantitatively within cyprinid populations, appears to be between 4 and $5 \%$ of the genome, as estimated from the average maximum genome size variation among all 49 populations surveyed. This quantity is approximately the same as that theoretically needed for the cyprinid structural gene component if one assumes the latter contains 50000 coding nuclear genes per genome and there are 1500 coding DNA base pairs per gene. It seems unlikely, however, that coding structural genes would be regularly gained or lost from a genome without eventually resulting in a phenotypic disturbance or developmental irregularity. This suggests that up to $90 \%$ of the cyprinid genome is maintained quantitatively even though no specific functions are known for this DNA. As noted previously (Gold and Price, 1985), both the normality of distributions within cyprinid populations and the apparent constraints on the quantity of DNA which can vary strongly imply the action of stabilizing or normalizing selection operating through the truncation of deleterious extremes (Stebbins, 1966; Mettler and Gregg, 1969). However, while natural selection may be influencing genome size variation within cyprinid populations, there is no evidence at present to indicate that selection favours a particular cyprinid species DNA value relative to some organismal parameter (Gold and Amemiya, 1987).

Two suggestions to account for interspecies genome size differences are the selfish DNA hypothesis (Doolittle and Sapienza, 1980; Orgel and Crick, 1980) and the hypothesis that genome size changes might occur primarily during speciation episodes (Hinegardner, 1976; Morescalchi, 1977; Cavalier-Smith, 1978). The basis for the former is that most eukaryotic genomes contain DNA sequences that can increase in copy number through differential replication. Presumably, these sequences are phenotypically inconsequential, at least to the point where the energy expended in replicating such DNA begins to infringe on the energy needs of the organism (Doolittle and Sapienza, 1980). In a very general way, the cyprinid genome 
size data are not inconsistent with the selfish DNA hypothesis in that: (i) there is significant variation in genome size within cyprinid populations which presumably is phenotypically inconsequential; (ii) species DNA values appear to be more or less randomly distributed within the variation which occurs; and (iii) individuals at the high end of the genome size distribution appear to be removed by negative selection. Alternatively, one might predict that if selfish DNAs contribute significantly to genome size variation, the underlying distributions of DNA values should not be normal. Species or populations where selfish DNAs are proliferating should show distributions skewed towards higher values; whereas, species or populations where selfish DNAs have accumulated to the point of impairing energy needs should show distributions skewed towards lower values. The genome size distributions in most cyprinid populations, however, are normal, and there appears to be no general tendency towards skewness in either direction.

The comparison of the means and variances of genome size distance between the cyprinid genus Notropis (species-rich phylad) versus the centrarchid genus Lepomis (species-poor phylad), suggests that considerable genome size change may occur during or be associated with cyprinid speciation episodes. Such a hypothesis is not contradicted by the findings that: (i) genome size variation within cyprinid populations is generally less than that among cyprinid species; (ii) cyprinid species genome sizes appear to be continuously and more or less randomly distributed within the variation which occurs; and (iii) there are no apparent associations between species genome sizes and various life-history characteristics (Gold and Price, 1985; Gold and Amemyia, 1987; this paper). A point to note, however, is that the evidence is essentially correlative and it would be difficult to determine experimentally whether the correlation was one of cause and effect or one of association. Moreover, intraspecific variation in genome size in both cyprinids and centrarchids can often be as great as the differences among species (Gold and Amemyia, 1987; Ragland and Gold, 1989; this paper). This raises some doubt as to the strengh or validity of the apparent correlation between genome size differentiation and speciation since, as noted by Ragland and Gold (1989), the generally lower intraspecific variation observed could stem from the homogenizing effects of gene flow within species.

On the other hand, the finding that ratios of mean genome size distance and variance in the Notropis versus Lepomis comparison differ markedly from those reported for structural genes and morphology suggests that different levels of the genome may follow independent evolutionary paths. The simplest explanation for the difference in distance and variance ratios is that genome size evolution is dependent, in part, on speciation episodes, whereas structural gene and morphological evolution are dependent primarily on elapsed time. This explanation is unquestionably oversimplified and is based on the assumptions that: (i) the models of Avise and Ayala (1975, 1976) and Avise (1978) are appropriate and sufficiently robust, and (ii) Notropis and Lepomis are appropriate taxa for comparison. Neither assumption is without caveats (Avise, 1977; Mayden 1986), nor have the models been tested or used in any other organismal group outside of cyprinid and centrarchid fishes. Moreover, exactly how or why the difference might occur is somewhat problematic given the difficulty in studying speciation in situ nascendi, as well as the wide variety of speciation modes (White, 1978; Templeton, 1980) theoretically pos- 
sible for any given speciation event. At this point, the conservative thesis is that genome size evolution may be decoupled from other levels of genome organization, and that genome size may, in fact, evolve in a "quantized" fashion as suggested by Cavalier-Smith (1985b).

\section{ACKNOWLEDGMENTS}

We thank Chris Amemiya, Tony Echelle, Gary Garrett, Bill Karel, Mike Howell, Bill Matthews and Bob Stiles for assistance in collecting the specimens used in this study, and we gratefully acknowledge the use of facilities at the Department of Biology at Samford University in Birmingham during our field work in Alabama, and the University of Oklahoma Biological Station on Lake Texoma during our field work in Oklahoma. We also thank Jim Price, John Bickham and the editors of the journal for constructive comments on the manuscript, and Laura Vilander for assistance in scanning a few of the microscope slides. The scanning microdensitometer, used in the research, was made available by $\mathrm{Dr} \mathrm{Jim}$ Price of the Soil and Crop Sciences Department at Texas A \& M University. The chicken blood, used as an internal standard, was provided by Dr Syed Naqi of the Texas A \& M College of Veterinary Medicine. The work was supported by project $\mathrm{H}-6703$ of the Texas Agricultural Experiment Station and by National Science Foundation grant BSR-8415428. This paper represents part III in the series "Genome size variation in North American minnows (Cyprinidae)."

\section{REFERENCES}

Avise JC (1977) Is evolution gradual or rectangular? Evidence from living fishes. Proc Natl Acad Sci USA 74, 5083-5087

Avise JC (1978) Variances and frequency distributions of genetic distance in evolutionary phylads. Heredity 40, 225-237

Avise JC, Ayala FJ (1975) Genetic change and rates of cladogenesis. Genetics 81, 757-773

Avise JC, Ayala FJ (1976) Genetic differentiation in speciose versus depauperate phylads: evidence from the California minnows. Evolution 30, 46-58

Bachmann K, Goin OB, Goin CJ (1972) Nuclear DNA amounts in vertebrates. Brookhaven Symp Biol 23, 419-450

Bennett MD (1971) The duration of meiosis. Proc $R$ Soc London, Ser B, 178, 277299

Bennett MD (1972) Nuclear DNA content and minimum mitotic time in herbaceous plants. Proc $R$ Soc London, Ser B, 181, 109-135

Bennett MD, Smith JB (1976) Nuclear DNA amounts in angiosperms. Phil Trans $R$ Soc London Ser $B$ 274, 227-274

Cavalier-Smith T (1978) Nuclear volume control by nucleoskeletal DNA, selection for cell volume and growth rate, and the solution of the DNA C-value paradox. $J$ Cell Sci 34, 247-278 
Cavalier-Smith T (1980) $r$ - and K-tactics in the evolution of protist developmental systems: cell and genome size, phenotype diversifying selection and cell cycle patterns. Biosystems 12, 43-59

Cavalier-Smith $\mathrm{T}$ (1985a) Introduction: the evolutionary significance of genome size. In: The Evolution of Genome Size. (Cavalier-Smith T, ed) Wiley, New York, $1-36$

Cavalier-Smith T (1985b) Cell volume and the evolution of eukaryotic genome size. In: The Evolution of Genome Size. (Cavalier-Smith T, ed) Wiley, New York, 105184

Cavender TM, Coburn MM (1986) Cladistic analysis of eastern North American Cyprinidae. Ohio J Sci 86, 1

Coburn MM (1982) Anatomy and Relationships of Notropis atherinoides. Ph.D. dissertation, Ohio State University, Columbus, $\mathrm{OH}$

Doolittle WF, Sapienza F (1980) Selfish genes, the phenotype paradigm and genome evolution. Nature 284, 617-618

Douglas ME, Avise JC (1982) Speciation rates and morphological divergence in fishes: tests of gradual versus rectangular modes of evolutionary change. Evolution $36,224-232$

Gibbs RH Jr (1957) Cyprinid fishes of the subgenus Cyprinella of Notropis. I. Systematic status of the subgenus Cyprinella, with a key to the species exclusive of the lutrensis-ornatus complex. Copeia 1957, 185-195

Gilbert CR (1964) The American cyprinid fishes of the subgenus Luxilus (genus Notropis). Bull Fla State Mus Biol Ser 8, 95-194

Gold JR, Price HJ (1985) Genome size variation among North American minnows (Cyprinidae). I. Distribution of the variation in five species. Heredity 54, 297-305

Gold JR, Amemiya CT (1987) Genome size variation in North American minnows (Cyprinidae). II. Variation among 20 species. Genome 29, 481-489

Hinegardner R (1976) Evolution of genome size. In: Molecular Evolution (Ayala FJ, ed) Sinauer Press, Sunderland, MA, 179-199

Hubbs CL (1955) Hybridization between fish species in nature. Syst Zool 4, 1-20

Johnson OW, Utter FM, Rabinovitch PS (1987) Interspecies differences in salmonid cellular DNA identified by flow cytometry. Copeia 1987, 1001-1009

Kauffman S (1971) Gene regulation networks: a theory for their global structure and behaviors. In: Current Topics in Developmental Biology (Moscona AA, Monroy A eds) Academic Press, New York, 145-182

Lee DS, Gilbert CR, Hocutt CH, Jenkins RE, McAllister DE, Stauffer JR Jr (1980) Atlas of North American Freshwater Fishes. North Carolina Biological Survey Publication No. 1980-12

Mayden RL (1986) Speciose and depauperate phylads and tests of punctuated and gradual evolution: fact or artifact? Syst Zool 35, 591-602

Mayden RL (1989) Phylogenetic studies of North American minnows, with emphasis on the genus Cyprinella (Teleostei: Cypriniformes). Miscellaneous Publication No. 80, University of Kansas Museum of Natural History, Lawrence, KS 
Mayden RL, Matson RH (1988) Evolutionary relationships of eastern North American cyprinids: an allozyme perspective. 68th Annual Meeting of the American Society of Ichthyologists and Herpetologists, Ann Arbor MI, 23-29 June

Mettler LE, Gregg TG (1969) Population Genetics and Evolution, Prentice-Hall, Englewood Cliffs, NJ

Miller RR (1959) Origin and affinities of the freshwater fish fauna of western North America. Zoogeography. Am Assoc Adv Sci Publ 51, 187-222

Mirsky AE, Ris H (1951) The deoxyribonucleic acid content of animal cells and its evolutionary significance. J Gen Physiol 34, 451-462

Morescalchi A (1977) Phylogenetic aspects of karyological evidence. In: Major Patterns in Vertebrate Evolution (Hecht MK, Goody PC, Hecht BM, eds) Plenum Press, New York, 149-167

Narayan RKJ (1982) Discontinuous DNA variation in the evolution of plant species. The genus Lathyrus. Evolution 36, 877-891

Orgel LE, Crick FHC (1980) Selfish DNA: the ultimate parasite. Nature 284, 645646

Price HJ (1988a) DNA content variation among higher plants. Annals Missouri Bot Garden 75, 1248-1257

Price HJ (1988b) Plant genome size and the DNA C-value paradox. Plant Genet Newsl 4, 18-24

Price HJ (1988c) Nuclear DNA content variation within angiosperm species. Evol Trends Plants 2, 53-60

Price HJ, Chambers KL, Bachmann K (1981) Geographic and ecological distribution of genomic DNA content variation in Microseris douglasii (Asteraceae). Bot Gaz $142,415-426$

Price HJ, Chambers KL, Bachmann K, Riggs J (1986) Patterns of mean nuclear DNA content in Microseris douglasii (Asteraceae) populations. Bot Gaz 147, 496507

Ragland CJ, Gold JR (1989) Genome size variation in the North American sunfish genus Lepomis (Pisces: Centrarchidae). Genet Res 53, 173-182

SAS Institute Inc (1982) User's Guide: Statistics. SAS Institute Inc, Cary NC

Sessions SK, Larson A (1987) Developmental correlates of genome size in plethodontid salamanders and their implications for genome evolution. Evolution 41, 12391251

Sherwood SW, Patton JL (1982) Genome evolution in pocket gophers (genus Thomomys). II. Variation in cellular DNA content. Chromosoma 85, 163-179

Shuter BJ, Thomas JE, Taylor WD, Zimmerman M (1983) Phenotypic correlates of genomic DNA contents in unicellular eukaryotes and other cells. Am Nat 122, 26-44

Sneath PHA, Sokal RR (1973) Numerical Taxonomy. WH Freeman, San Francisco, CA 
Snelson FF Jr (1968) Systematics of the cyprinid fish Notropis amoenus, with comments on the subgenus Notropis. Copeia 1968, 776-802

Snelson FF Jr (1972) Systematics of the subgenus Lythrurus, genus Notropis (Pisces: Cyprinidae). Bull Fla State Mus Biol Ser 17, 1-92

Sokal RR, Rohlf FJ (1969) Biometry. WJ Freeman, San Fransisco, CA

Sparrow AH, Price HJ, Underbrink AG (1972) A survey of DNA content per cell and per chromosome of prokaryotic and eukaryotic organisms: some evolutionary considerations. Brookhaven Symp Biol 23, 451-494

Stebbins GL (1966) Processes of Organic Evolution. Prentice-Hall, Englewood Cliffs, NJ

Swift CC (1970) A review of the eastern North American cyprinid fishes of the Notropis texanus species group (subgenus Alburnops), with a definition of the subgenus Hydrophlox, and materials for a revision of the subgenus Alburnops. Ph.D. dissertation, Florida State University, Tallahassee, FL

Szarski $H$ (1983) Cell size and the concept of wasteful and frugal evolutionary strategies. $J$ Theor Biol 105, 201-209

Templeton AR (1980) Modes of speciation and inferences based on genetic distances. Evolution 34, 719-729

White MJD (1978) Modes of Speciation. WH Freeman, San Francisco, CA 


\section{APPENDIX}

Table AI. Collection localities of the 29 North American cyprinid species examined in this study.

\begin{tabular}{llll}
\hline Taxon & Collection site & Drainage & County and state \\
\hline Genus Notropis & & & \\
$N$ amabilis & Miller Cr & Pedernales R & Blanco, TX \\
$N$ ardens & Scroungeabout Cr & Tennesse R & Morgan, AL \\
$N$ atherinoides & S Canadian R & Arkansas R & Pottawatomie, OK \\
$N$ atrocaudalis & Little Cypress Bayou Cr & Red R & Harrison, TX \\
$N$ baileyi & Little Sandy Cr & Cahaba R & Bibb, AL \\
$N$ bellus & Buck Cr & Cahaba R & Shelby, AL \\
$N$ braytoni & Pecos R & Pecos R & Val Verde, TX \\
$N$ callistius & Cahaba R & Cahaba R & Jefferson, AL \\
$N$ camurus & W Thompsons Cr & Mississipi R & W Feliciana, LA \\
$N$ chrosomus & Cahaba R & Cahaba R & Jefferson, AL \\
$N$ emiliae & Lake Conroe & San Jacinto R & Montgomery, TX \\
$N$ lepidus & Nueces R & Nueces R & Real, TX \\
$N$ oxyrhynchus & Brazos R & Brazos R & Robertson, TX \\
$N$ potteri & Brazos R & Brazos R & Robertson, TX \\
$N$ proserpinus & Devils R & Devils R & Val Verde, TX \\
$N$ stilbius & Buck Cr & Cahaba R & Shelby, AL \\
$N$ texanus & W Chappepela Cr & Tangipahoa R & Tangipahoa, LA \\
$N$ trichroistius & Cahaba R & Cahaba R & Jefferson, AL \\
$N$ volucellus & Cahaba R & Cahaba R & Bibb, AL \\
& & & \\
Other genera & & & \\
Dionda episcopa & Devils R & Devils R & Val Verde, TX \\
Ericymba buccata & Little Sandy Cr & Cahaba R & Bibb, AL \\
Hemitremia flammea & Harrin Cr & Tennessee R & Morgan, AL \\
Hybognathus placitus & S Canadian R & Arkansas R & Pottawatomie, OK \\
Hybopsis aestivalis & Cahaba R & Cahaba R & Bibb, AL \\
$N$ Nocomis asper & Blue R & Red R & Johnston, OK \\
$N$ ocomis leptocephalus & Pushepatapa Cr & Pearl R & Washington, LA \\
Phenacobius catostomus & Buck Cr & Cahaba R & Shelby, AL \\
Phenacobius mirabilis & Caddo Cr & Red R & Carter, OK \\
Rhinichthys atratulus & Harrin Cr & Tennesse R & Morgan, AL \\
\hline & & & \\
\hline & & & \\
\hline
\end{tabular}


Table AII. Current classification ${ }^{a}$ of the North American cyprinid species examined for DNA content. ${ }^{a}$ Classification based on Gibbs (1957), Gilbert (1964), Snelson (1968, 1972), Swift (1970), Lee et al (1980), Coburn (1982) and Mayden (1989); $b$ The subgenus Hydrophlox may no longer be valid: Notropis baileyi may belong elsewhere in Notropis and Notropis rubellus appears to be closely related to Notropis atherinoides of the subgenus Notropis (Mayden and Matson, 1988; TE Dowling, personal communication); ${ }^{\mathrm{c}}$ Notropis atrocaudalis and Notropis stramineus may not be valid members of Notropis (Mayden, 1989); ${ }^{d}$ Notemigenus crysoleucas may be belong to a different subfamily than all other North American cyprinids (Hubbs, 1955; Miller, 1959); ${ }^{\mathrm{e}}$ The genus Pimephales appears most closely related to certain lineages (viz, Notropis emiliae and the subgenus Cyprinella) in the genus Notropis (Cavender and Coburn, 1986; Mayden and Matson, 1988).

Subgenus Alburnops

$N$ girardi

$N$ potteri

Subgenus Cyprinella

$N$ callistius

$N$ camurus

$N$ lepidus

$N$ lutrensis

$N$ proserpinus

$N$ trichroistius

$N$ venustus

$N$ whipplei

Subgenus Hydrophlox ${ }^{\mathrm{b}}$

$N$ baileyi

$N$ chrosomus

$N$ nubilus

$N$ rubellus

Subgenus Luxilus

$N$ chrysocephalus

$N$ pilsbryi
Genus Notropis

Subgenus Lythrurus
$N$ ardens
$N$ bellus
$N$ umbratilis

Subgenus Notropis

$N$ amabilis

$N$ atherinoides

$N$ oxyrhynchus

$N$ shumardi

$N$ stibius

$N$ texanus species group

$N$ texanus

$N$ volucellus species group

$N$ volucellus

Unknown affinities

$N$ atrocaudalis $^{\mathrm{c}}$

$N$ boops

$N$ braytoni

$N$ emiliae

$N$ stramineus ${ }^{\mathrm{c}}$

Other North American cyprinids

\begin{tabular}{ll} 
Campostoma anomalum & Notemigonus crysoleucas \\
Campostoma oligolepis & Phenacobius catostomus \\
Dionda episcopa & Phenacobius mirabilis \\
Ericymba buccata & Pimephales notatus \\
Hemitremia flammea & Pimephales promelas \\
Hybognathus placitus & Pimephales vigilax \\
Hybopsis aestivalis & Phoxinus erythrogaster \\
Nocomis asper & Rhinichthys atratulus \\
Nocomis leptocephalus & Semotilus atromaculatus \\
\hline
\end{tabular}

